\title{
KAJIAN PENERAPAN BUDIDAYA DAN PEMASARAN ITIK \\ (Studi Kasus pada Kelompok Ternak Itik Putri Mandiri \\ di Kabupaten Karawang Jawa Barat)
}

\author{
Oleh: \\ ASEP PERMADI GUMELAR \\ Universitas Garut \\ Email: digumdifagumelar@gmail.com \\ AGUNG RAHMAT \\ Universitas Garut \\ Email: hendayanto@yahoo.com
}

\begin{abstract}
Abstrak
Tujuan melakukan penelitian ini adalah untuk mengatahui: (1) Keadaan penerapan budidaya itik pada Kelompok Ternak Itik Putri Mandiri; (2) Keadaan pemasaran itik pada Kelompok Ternak Itik Putri Mandiri. Metode penelitai yang digunakan dalam penelitian ini adalah studi kasus dengan mengambil kasus pada Kelompok Ternak Itik Putri Mandiri. Pengambilan data dilaksanaan dengan teknik wawancara secara langsung dan analisis data dilakukan secara deskriptif. Hasil penelitian menunjukkan bahwa : (1) Keadaan penerapan budidaya itik pada Kelompok Ternak Itik Putri Mandiri mencangkup pemberian pakan, pengambilan telur, teknik pencahayaan dan penggunaan litter, biosekuriti dan sanitasi, program pencegahan penyakit, penanganan limbah cukup baik, walaupun masih banyak yang harus diperbaiki semisal tata letak kandang dan program pemberian cahaya; (2) Harga jual telur dalam pemasaran itik antara Rp. 1.200-Rp 1.400,- per telur dan harga itik afkir Rp.32.000- Rp.35.000 per ekor. Rantai. Penjualan ada yang langkung ke konsumen dan ada yang melalui pasar.
\end{abstract}

Kata Kunci: itik, penerapan, budidaya, pemasaran

\section{PENDAHULUAN}

Salah satu sumberdaya alam yang berpeluang untuk dikembangkan adalah ternakitik karena cukup banyak daerah di Indonesia yang telah membuat sentral-sentral produksi teluritik dan telah menjadi usaha pokok masyarakat. Menurut Direktorat Jendral Peternakan (2010) data produksi telur di Indonesia pada tahun 2006, 2007 dan 2009 berturut-turut adalah 193.630 ton, 207.535 tondan 200.989 ton.Jumlah tersebut menunjukan bahwa produksi telur itik semakin tahun me-ningkat akan tetapi pada tahun 2009 mengalami penurunan.Untuk meningkatkan produksi telur di Indonesia, provinsi Jawa Barat dapat memberikan kontribusi dengan meningkatkan produksi telur itikdengan baik.Adapun produksi telur di Jawa Barat pada tahun 2006 sebanyak 34.632 ton, tahun 2007 sebanyak 42.726 ton dan tahun 2009 sebanyak 43.822 ton.Hal ini menjadikan sebuah peluang untuk peternak itik baru.

Kelompok Ternak Itik Putri Mandiri merupakan salah satu kelompok peternakan bergerak dalam bidang produksi teluritik konsumsi yang melakukan kegiatan

pemeliharaan itik Karawang yang dipelihara secara semi intensif.

Tujuan melakukan penelitian ini adalah untuk mengatahui:

1. Keadaan penerapan budidaya itik pada Kelompok Ternak Itik Putri Mandiri

2. Keadaan pemasaran itik pada Kelompok Ternak Itik Putri Mandiri.

\section{TINJAUAN PUSTAKA}

Itik merupakan unggas yang memiliki keunikan dilihat dari berbagai sisi misalkan pola pemeliharaan yang tidak susah, pemberian pakan dapat ditekan seminimal mungkin agar mendapatkan keuntungan yang lebih baik. Di Provinsi Jawa Barat khususnya di Karawang nama itik sangat beragam sesuai dengan periode pertumbuhannya, periode starteritik dikenal dengan istilah cicit setelah periode groweritik dikenal dengan istilah titik, itik periode layer dikenal dengan istilah bebek. Nenek moyang itik berasal dari Amerika Utara yang merupakan itik liar Anas moschaatau Wild Mallard. Untuk mendapatkan keuntungan baik serta ras yang produksi telur berkualitas baik, daging yang berkualitas tinggi itik terus menerus dijinakkan 


\section{MIMBAR \\ A GRIBISNIS \\ ISSN 2460-4321}

Volume 1・ Nomor 1・Juli 2015

oleh manusia hingga jadilah itik yang diperlihara sekarang yang disebut Anas domesticus atau ternakitik.Apabila menginginkan itik petelur, bibit yang dipelihara harus berasal dari itik petelur. berpenampilan tubuh relatif tegak dan kuat berjalan jauh. Ciriciri lainnya, itik petelur mempunyai bentuk tubuh seperti botol dengan leher panjang, kakinya cukup besar, perut mengge-lantung di antara kedua kakinya, mata cerah bersinar, serta geraknya lincah (Windhyarti, 2009).Beberapa jenis itik petelur seperti itik Karawang, itik Mojosari, itik Tegal, itik Magelang, itik Alabio dan itik Bali (Wakhid, 2010).

Kandang merupakan sarana utama dalam peternakan, terutama pada peme-liharaan itik secara intensif. Fungsi kandang diantaranya untuk melindungi ternak dari gangguan hewan liar, tempat berlindung dari panas dan hujan, tempat makan dan minum, serta untuk memudahkan pemeliharaan (Wakhid, 2010).

Pemeliharaan itik dalam kandang (secara intensif) memberikan keuntungan lebih bagi peternak, diantaranya untuk meningkatkan produktivitas itik petelur dan mengoptimalkan peningkatan bobot badan itik pedaging. Itik yang dipelihara di dalam kandang kondisinya menjadi lebih tenang dibandingkan dengan itik yang tidak dikandangkan. Selain itu mengandangkan itik bisa mencegah kemungkinan kematian karena memakan makanan yang mengandung racun atau bangkai.Lokasi kandang ditempatkan ditempat yang tenang jauh dari keramaian dan tidakberdekatan dengan perumahan. Kandang yang dekat dengan keramaian misalnya dekat dengan jalan raya, lintas kereta api, lapangan tembak dan lain sebagainya dapat menimbulkan itikstres. Kondisi ini dapat mengganggu pertumbuhan itik dan produksi telur (Supriyadi, 2010).

Pemberian pakan merupakan faktor yang sangat penting dan strategis dalam peningkatan produksi dan produktivitas ternakitik, pakan itik terdiri dari campur-an bahan baku pakan, baik yang diolah maupun yang belum diolah. Sebelum memulai beternak tentunya harus mengetahui kebutuhan zat gizidan kandungan dari bahan-bahan baku pakan yang dipergunakan, terutama menyusun pakan sendiri. Mengetahui komposisi bahan pakan yang dapat menghemat biaya pakan, tetapi hasilnya tidak jauh berbeda dengan pakan buatan pabrik (Supriyadi, 2009).

Kebutuhan zat gizi itiklayer membutuhkan pakan dengan kandungan pro-tein $15-18 \%$ dan kandungan energi sebesar 2.700 kkal. Pemberian pakan untuk itik dewasa setelah umur 5 bulan berupa pakan bentuk tepung sebanyak 100 gram dan pakan butiran sebanyak 60 gram. Total pakan yang diberikan sekitar 160 gram per ekor per hari, pemberian pakan diberikan tiga kali sehari, yaitu pagi pukul 07.30, siang hari pukul 12.00 dan sore hari 17.00 (Wakhid, 2010).

Pemberian air minum ad libitum. Air yang diberikan harus tersedia di dalam tempat air minum. Sebagai patokan, itikstarter membutuhkan air minum sekitar 0,2 sampai 0,3 liter per ekor per hari. Itik remaja dan itik dewasa membutuhkan 0,5 liter per ekor per hari. Dengan demikian, peternak dapat memperkirakan jumlah air minum yang harus disediakan per hari (Supriyadi, 2010).

\section{METODE PENELITIAN}

Metode penelitai yang digunakan dalam penelitian ini adalah studi kasus dengan mengambil kasus pada Kelompok Ternak Itik Putri Mandiri . pengambilan data dilaksanaan dengan teknik wawancara secara langsung dan menganalisis kondisi lokasi peternakan, pelaksanaan kegiatan kelompok tani dibawah pengawasan pembimbing lapangan seperti:

1. Memberikan pakan secara teratur pagi dan sore, pakan yang diberikan berupa campuran dedak dan jagung dengan perbandingan yang telah disesuaikan de-ngan kebutuhan 2: 1 (2 dedak, 1 jagung) dan ikan rucah sebagai protein hewani.

2. Menjaga kandang tetap hangat, nyaman dan menjaga telur agar tidak terben-tur denganlantai kandang dengan diberi alas atau litter.

3. Pengambilan telur dipagi hari sekitar pukul 06.30 wib dan melakukan penca-tatan produksi telur per hari.

4. Melakukan pencegahan penyakit dengan menerapkan biosecurity dan sanitasi secara rutin.

5. Memasarkan hasil produksi telur itik kepasar atau biasanya pembeli yang datang ke tempat. 


\section{ASEP PERMADI GUMELAR}

\section{AGUNG RAHMAT}

Data sekunder yang dikumpulkan dari pihak yang telah disebutkan di atas dengan studi pustaka dari berbagai bahan bacaan yang menunjang serta sumber lainnya yang berkaitan dengan permasalahan. Analisis data dilakukan secara deskriptif

\section{HASIL DAN PEMBAHASAN Sejarah dan Perkembangan}

Kelompok Budidaya TernakItik Putri Mandiri dibentuk atas dasar musyawarah anggota masyarakat peternak di Dusun Sumberjati Desa PusakaJaya Selatan Kecamatan Cilebar Kabupaten Karawang. Kelompok ini berdiri pada 11 Januari 2008 dengan jumlah anggota 10 orang. Anggota kelompok memiliki latar belakang mata pencaharian sebagai petani, buruh dan peternak.

KelompokTernakItik Putri Mandiri memperoleh bantuan modal dari program SMD (Sarjana Membangun Desa),Direktorat Jendral Peternakan KE-MENTAN RI,sebesar Rp.105.000.000,00.- (seratus lima juta rupiah) pada tahun 2010. Modal ini digunakan untuk mengembangkan usaha peternakan, perbaikan kontruksi kandangpeternakan, membeli perlengkapan sarana prasarana penunjang produksi, pengadaan ternakitik, kebutuhan pakan, dan sarana produksi. Sesuai dengan program SMD KelompokTernakItik Putri Mandiri yaitu menjadikan KelompokTernakItik Putri Mandiri sebagai sentral peternakanitik di Karawang.

Seiring dengan perkembangan KelompokTernakItik Putri Mandiri dalam pemasaran cukup baik karena berdekatan dengan kota Jakarta sangat strategis untuk pemasaran telur dan itik afkir. Terbukti banyaknya restoran dan rumah makan yang menyajikan telur ataupun daging olahan dari itik.

\section{Ketenagakerjaan}

KelompokTernakItik Putri Mandiri mengangkat dua karyawan tenaga kerja untuk membantu kelancaran produksi, merawat ternak memberi makan setiap harinya. Diadakan tenaga kerjaan ini membantu kelompok yang tidak dapat memeliharan ternakitik karena terhalangnya pekerjaan diladang maupun terpanggilnya menjadi karyawan pabrik dan keterbatasan waktu. Ketenagakerjaan yang dilimpahkan pada karyawan memiliki tugas saling mengisi tidak saling membedakan pembagian pekerjaan. Waktu pemberian pakan mulai pukul 07.00 WIBuntuk pemberian pakan pagi, pukul 15.30 WIB pemberian pakan sore. Kegiatan yang dilakukan selama proses pemeliharaan seperti pemberian pakan ikan rucah dan campuran dedak dan jagung, mencuci tempat pakan dan minum sebelum digunakan, pemberian jerami atau serutan kayudisarang bertelur supaya telurtidak banyak yang retak, membersihkan kandang satu kali sehari pada sore hari pada halaman.

Jadwal kerja karyawan ditentukan oleh pendamping SMD. Waktu kerja disesuaikan waktu pemberian pakan 2 kali pagi dan sore. Karyawan menghabis-kan lama efektif kerja sebanyak 8 jam/hari.

\section{Sarana dan Prasarana}

Sarana dan prasarana yang digunakan KelompokTernakItik Putri Mandiri sebagai kelancaran produksi diantaranya adalah bangunan kandang yang terdiri dari 3 kandang masing-masing sekat diberi jarak $11 \mathrm{~m} \mathrm{x} \mathrm{3,5} \mathrm{m,}$ yang masing-masing bangunan kandang terbagi menjadi beberapa koloni, selain kandang terdapat gudang pakan dan gudang penyimpanan telur. Perlengkapan yang digunakan masih tradisional meliputi bak pakan, selang air, penggiling ikan manual, timbangan duduk, karung dan egg tray.

\section{Perkandangan}

Kandang yang dibangun oleh KelompokTernakItik Putri Mandiri adalah kandang panggung diatas kolam ikan lele disebut dengan istilah longtik (balong itik), bahan kandang yang digunakan hampir semua terbuat dari bambu kecuali atap terbuat dari bahan terpal. Alas kandangtidak diberi litter, agar kotoran dan pakanyang tercecer dapat langsung jatuh ke kolam. Halaman kandang terbuat dari semen dan diberi batas sekat antara kandang selain itu terdapat kubangan air memanjang berfungsi untuk tempat minum dan mandi itik. Ukuran kubangan air pada halaman kandangyaitupanjang $18 \mathrm{~m}$ dengan kedalaman kubangan kurang lebih $12 \mathrm{~cm}$ dan lebar $15 \mathrm{~cm}$, halaman kandang agar itiktidak terlalu panas diberi atap yang terbuat dari bambu dan karung bekas kemudian di sambung menjadi atap. 


\section{AIMBAR \\ Agribisnis \\ ISSN 2460-4321}

Volume $1 ・$ Nomor $1 ・$ Juli 2015

Sistem pemeliharaan yang digunakan oleh KelompokTernakItik Putri Mandiri yaitu sistem semi intensif. Dalam sistem ini, itik sudah dikandangkan menggunakan kandang yang memadai.Supaya mempermudah pengontrolan kesehatan dan pemberian pakan.

Kandang pemeliharaan terbagi menjadi 10 sekat, untuk ukuran persekat $11 \mathrm{~m} \mathrm{x} \mathrm{3,5} \mathrm{m} \mathrm{diisi}$ dengan jumlah 100 ekor per kandang. Gambar kandang dapat dilihat pada Gambar 1.

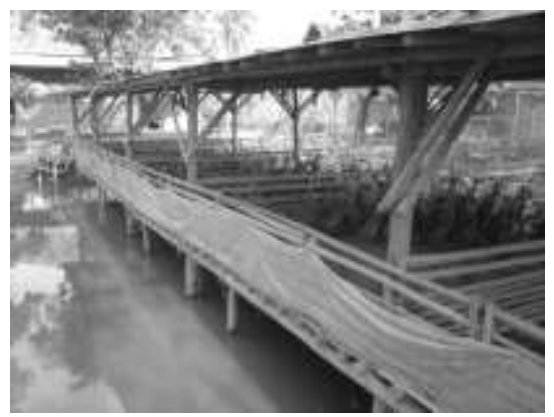

Gambar 1 Kandang Itik Kelompok Ternak Itik Putri Mandiri

\section{Jumlah dan Jenis Itik yang Dipelihara}

KelompokTernakItik Putri Mandiri memelihara itik sebanyak 980. Setiap anggota memeliharan 100 ekor itik tetapi setelah berjalannya proses peme-liharaan selama 3 bulan anggota kelompok banyak yang menyerahkan ke ketua kelompokkarena terhalangnya pekerjaan diladang dan keterbatasan waktu, pelimpahan pemeliharaan itiktidak ada unsur paksaan. Itik yang dipelihara oleh KelompokTernakItik Putri Mandiri adalah itik petelur Karawang. Keunggulan produktivitas bertelur pada itik Karawang ini cukup tinggi mencapai 270 butir per ekor per tahun dan ukuran telur rata-rata 65 gram per butir. Jenis itik Karawang dapat dilihat pada Gambar 2.

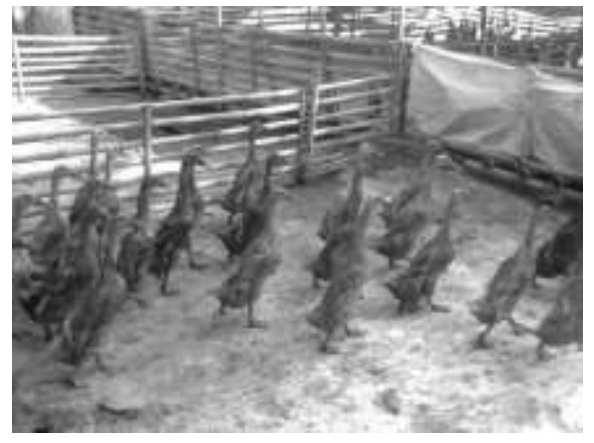

Gambar 2 Itik Karawang

\section{Pemeliharaan Itik Periode Layer (60 sampai 68 minggu)}

Pemeliharaan periode layer bertujuan untuk menghasilkan telur konsumsi yang berproduksi tinggi. Saat melakukan kegiatan PKL itik Kelompok Ternak Itik Putri Mandiri berumur 60 minggu sampai 68 minggu. Untuk mendapatkan pro-duksi telur yang tinggi, harus didukung dengan tempat yang nyaman, sesuai dengan kebiasaan itik, jauh dari keramaian dan bising. Kondisi di KelompokTernakItik Putri Mandiri belum memenuhi syarat yang mendukung peningkatan produksi telur, sebagai contoh kandang dekat dengan pemukiman.Itik mulai afkir sekitar umur 144 minggu. Itik yang dipelihara adalah itik petelur Karawang.

Keunggulan itik Karawang produktivitas bertelur pada itik Karawang ini cukup tinggi mencapai 250 butir per ekor per tahun dan ukuran telur rata-rata 65 gram per butir (Wakhid, 2010).

\section{Pemberian Pakan dan Air Minum}

KelompokTernakItik Putri Mandiri berlokasi di Karawang yang banyak terdapat penggilingan padi, sehingga peternak mudah memperoleh dedak atau menir sebagai pakan sumber karbohidrat. Untuk memenuhi kebutuhan protein, peternak memanfaatkan keong mas yang diperoleh dari sekitar pesawahan dan rawa-rawa atau ikan rucah dari laut. Pemberian pakan yang diberikan disesuaikan dengan jumlah itik perkandang, suhu lingkungan, kondisi kesehatan, bobot badan. Jenis pakan (Wakhid, 2010). Pakan yang diberikan dedak padi, jagung sebagai sumber energi, sebagai sumber protein hewani digunakan ikan rucah. Eceng gondok diberikan pada pukul 09.30 WIB setiap 2 hari sekali.Hal ini merupakan salah satu pemanfaatan dari gulma air yang sering merusak lingkungan dan tidak dimanfaatkan dapat dipergunakan sebagai salah satu bahan pakan yang bisa menekan harga ransum. Pemberian eceng gondok pada itiktidak mempunyai pengaruh negatif terhadap produksi telur baik dari segi berat maupun jumlah. Penggunaan eceng gondok itu berpengaruh terhadap warna kuning telur. Pem-berian pakan dilakukan 2 kali yaitu pagi (07.00 WIB) dan sore (15.30 WIB). Pakan yang diberikan berupa campuran dedak dan jagung dengan perbandingan $2: 1$ (2 dedak, 1 


\section{ASEP PERMADI GUMELAR}

\section{AGUNG RAHMAT}

jagung). Jumlah pakan yang diberikan sebanyak $19 \mathrm{~kg} / \mathrm{sekat} / \mathrm{hari}$ berupa campuran dedak dan jagung $10 \mathrm{~kg}$ serta ikan rucah $9 \mathrm{~kg}$ yang terdiri dari 10 sekat dengan populasi itik per sekat 100 ekor, untuk sekat nomor 10 jumlah itik sebanyak 80 ekor diberikan pakan sebanyak $12,5 \mathrm{~kg}$.

Konsumsi pakan per ekor190 gram/hari, 100 gram/ekor/hari antara campuran dedak dan jagung serta ikanrucah 90 gram/ekor/hari dengan persentase pemberian pakan yaitu dedak $35 \%$, jagung $17 \%$, dan ikan rucah $48 \%$. Pakan yang diberikan dibiarkan habis terlebih dahulu, kemudian tempat pakan dan air minum dibersihkan.

Pemberian air minum menggunakan bak air minum, yang biasanya peng-gunaan dengan bak ketika akan menjelang sore hari.Bentuk bak air minum dan mandi itik disajikan pada Gambar 3.

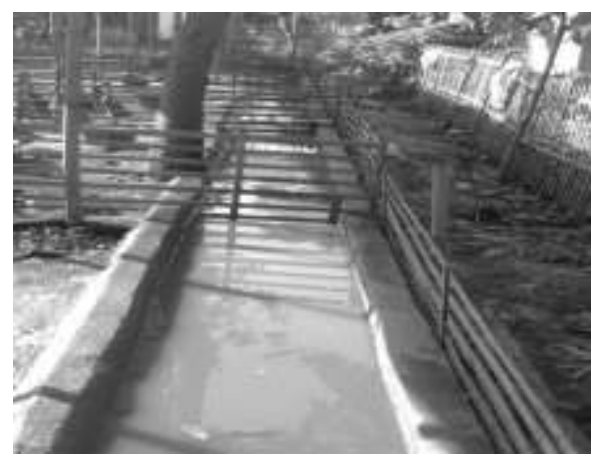

Gambar Saluran Air Minum dan Mandi Itik

\section{Program Pemberian Cahaya dan Penggunaan Litter}

Tujuan program pemberian cahaya berfungsi untuk merangsang produksi telur dan meningkatkan konsumsi pakan (Wakhid, 2010). KelompokTernakItik Putri Mandiri tidak melakukan program pemberian cahaya. Hal ini beranggapan akan membuat itikmudahstres oleh kejutan kedatangan kelelawar kedalam kandang dan menggangu produksi telur.

Litter menggunakan jerami padi yang merupakan limbah hasil pertanian disekitar tempat peternakan.Litter digunakan untuk sarang bertelur sebagai peng-hangat tubuh itik pada malam hari dan mengurangi benturan ke dasar lantai.

Pengambilan Telur

Itik mulai bertelur dari jam 03.00 pagi hingga sekitar pukul 08.00pagi, karena itu pengambilan telur dapat dilakukan setelahnya. Pengambilan telur pada kandang koloni atau kandang ren dilakukan dengan mengarahkan itik ke bagian teras, agar petugas kandang dapat leluasa memungut telur tanpa mengganggu itik (Wakhid, 2010).Pengambilantelurdi Kelompok Ternak Itik Putri Mandiri di-lakukan pada pagi hari sekitar pukul 06.30 WIB, kegiatan ini dilakukan secara rutin, bertujuan agar itiktidak mengalami stres dan kegiatan pengambilan telur dilakukan setelah itik dikeluarkan dari kandang tempat istirahat. Pengambilan telur dilakukan oleh orang yang sama, hal ini bertujuan untuk mencegah stres pada itik. Tempat yang digunakan untuk pengambilan telur ialah keranjang yang diberi alas jerami atau serutan kayu,Setelah semua telur terkumpul dan dilakukan pencatatan produksi telur perkandang, telur disimpan ke dalam gudang.

\section{Produksi Telur}

Produksi telur di KelompokTernakItik Putri Mandiri pada saat pelaksanaan penelitian sedang mengalami penurunan hingga mencapai $50 \%$ (Tabel 1).

Penghitungan produksi telur adalah :

\section{$\sum$ telur dalam satu minggu $\overline{\text { populasi itik dalam satu minggu }} \times 100 \%$}

Hal ini dikarenakan itik sedang mengalami molting (rontok bulu). Kondisi tersebut terjadi tidak serempak dikarenakan umur itik yang tidak seragam.Pro-duktivitas bertelur pada itik Karawang ini cukup tinggi mencapai 270 butir per ekor per tahun (Wakhid, 2010). Pada minggu ke 5 mulai dilakukan pengafkiran pada itik yang berproduksi telur rendah, itik yang diafkir sejumlah 300 ekor. 


\section{AIMBAR \\ Agribisnis \\ ISSN 2460-4321}

Volume $1 \cdot$ Nomor $1 \cdot$ Juli 2015

Tabel 1 Produksi Telur per minggu di KelompokTernakItik Putri Mandiri

\begin{tabular}{|c|c|c|c|c|c|c|}
\hline $\begin{array}{l}\text { Minggu } \\
\text { ke }\end{array}$ & $\begin{array}{l}\text { Umur } \\
\text { (Minggu) }\end{array}$ & $\begin{array}{c}\text { Jumlah } \\
\text { Itik } \\
\text { /Hari }\end{array}$ & $\begin{array}{l}\text { Jumlah } \\
\text { Itik } \\
\text { /Minggu }\end{array}$ & $\begin{array}{l}\text { Afkir } \\
\text { (ekor) }\end{array}$ & $\begin{array}{l}\text { Produksi } \\
\text { Telur } \\
\text { /Minggu }\end{array}$ & $\begin{array}{c}\text { Produksi } \\
\text { Telur } \\
\text { Duck } \\
\text { Day(\%) }\end{array}$ \\
\hline 1 & 60 & 980 & 6860 & - & 3055 & 44,53 \\
\hline 2 & 61 & 980 & 6860 & - & 3454 & 50,35 \\
\hline 3 & 62 & 980 & 6860 & - & 3502 & 51,05 \\
\hline 4 & 63 & 980 & 6860 & - & 2628 & 38,31 \\
\hline 5 & 64 & 880 & 6160 & 100 & 1466 & 23,80 \\
\hline 6 & 65 & 780 & 5460 & 100 & 1196 & 21,90 \\
\hline 7 & 66 & 780 & 5460 & - & 941 & 17,23 \\
\hline 8 & 67 & 680 & 4760 & 100 & 1013 & 21,28 \\
\hline 9 & 68 & 680 & 4760 & - & 1558 & 32,73 \\
\hline
\end{tabular}

Sumber: KelompokTernakItikPutri Mandiri (2011)

Data Tabel 1 menunjukan bahwa, produksi telurumur 60 minggu sampai 62 minggu mengalami peningkatan sampai $50 \%$. Produksi telur mulai menurun pada umur 63minggu sampai umur 67 minggu setelahitu produksi mulai meningkat lagi. Hal ini dikarenakan kondisi itik dalam keadaan rontok bulu molting. Kondisi molting ini merupakan genetik dari itik untuk memperbaiki reproduksi pada itik, kondisi molting akan terjadi selama 40 hari atau lebih ter-gantung perlakuan yang dilakukan peternak (Hardjosworo dan Rukmiasih, 2009).

\section{Program Pencegahan Penyakit}

Biosekuriti adalah suatu tindakan untuk menghindari dari kontak antara hewan dan mikroorganisme dan merupakan pintu pertahanan pertama dalam upaya pengendalian suatu penyakit (Akhirany, 2010).Biosekuriti yang dilakukan KelompokTernakItik Putri Mandiri meliputi penyemprotan menggunakan desin-fektan dengan merk dagang Glutacap sebanyak 5 liter. Penyemprotan dilakukan setiap 2 minggu sekali pada kandang, serta halaman perkandangan.

Sanitasi yang dilakukan yaitu membersihkan, lantai kandang dengan peralatan sapu dibarengi dengan semprotan air, bak pakan dan tempat air minum dan tempat berenang setiap hari, agar kondisi air tetap bersih.

\section{Rontok Bulu (Molting)}

Pada akhir masa produksi telur, itik akan mengalami rontok bulu yang ditandai dengan terhentinya produksi telur, terlepasnya bulubulu dalam jumlah banyak dan diikuti dengan tumbuhnya bulu-bulu baru sebagai pengganti bulu lama. Pada intinya, masa rontok bulu merupakan masa istirahat dan masa perbaikan alat reproduksi setelah bertelur selama 8-10 bulan (Supriyadi, 2010).Perlakuan rontok bulu yang dilakukan di KelompokTernakItik Putri Mandiriadalah dengan pemuasaan selama 1 minggu tidak diberi makan atau sampai mencapai penurunan bobot badan sekitar 20 $\%$.Setelah itu itik diberi makan kembali.Itik yang sedang rontok bulu cenderung banyak makan, tetapi produksi telur menurun.

\section{Penggunaan Sarang (Nest Box)}

Sarang adalah tempat berteluritik yang berbentuk kubus dengan ukuran $30 \mathrm{~cm}$ x 30 $\mathrm{cm}$.Sarang digunakan agar itik dapat bertelur pada tempat yang nyaman dan agar telurtidak tercecer di sembarang tempat. Kapasitas 1 petak nest box untuk 4 - 5 ekor. Sarang yang digunakan pada pemeliharaan itiktidak terdapat tempat bertengger seperti halnya pada ayam.Bentuk sarang bertelur disajikan pada Gambar 4. 


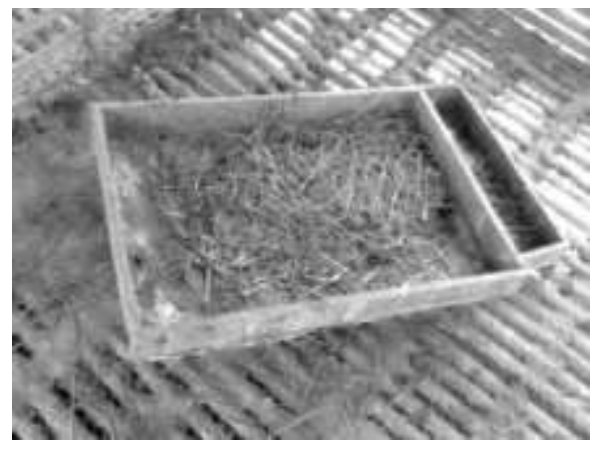

Gambar 4 Sarang Bertelur Itik

\section{Penanganan Limbah}

Limbah menjadi masalah yang akan timbul apabila dalam penanganantidak serius. Apabila dilakukan pengolahan yang baik, limbah tersebut dapat dijadikan pendapatan tambahan. KelompokTernakItik Putri Mandiri penanganan yang dilakukan cukup baik limbah cair ataupun limbah padat. Penanganan limbah cair yang terdapat merupakan sisa dari pencucian peralatan kandang, air berenang itik dan air minum. Pembuangan limbah cair terlihat pada Gambar 5.

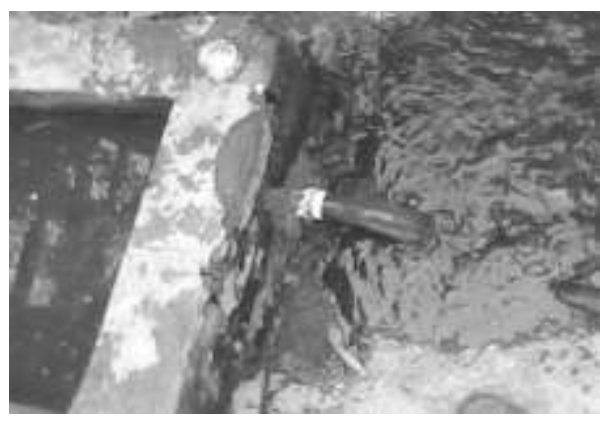

Gambar 5 Penanganan Limbah Cair

Limbah cair tidak ilakukan pemanfaatan hanya dibuang ke saluran irigasi yang ada dan tidak ada penanganan lebih lanjut lagi.

Penanganan limbah padat di KelompokTernakItik Putri Mandiri adalah berupa kotoran, jerami sebagailitter, kotoran dan bangkai itik. Penanganan limbah jerami digunakan untuk pupuk bagi pertanian, sedangkan untuk kotoran dan bangkai itik dimanfaatkan sebagai pakan ikan.

\section{Pemasaran}

Pemasaran merupakan proses sosial dengan proses individu dengan ke-lompok untuk mendapatkan apa yang dibutuhkan dan diinginkan dengan mencip-takan, penawaran dan secara mempertukarkan produk dan jasa yang bernilai dengan pihak lain (Wakhid, 2010).Pemasaran hasil produksi ditampung di ketua kelompok, penjualan telur biasanya dibawa langsung kepasar di Daerah Rengas Dengklok atau pembeli yang datang langsung ke tempat untuk diolah menjadi telur asin.

\section{Produk dan Harga Jual}

Produk yang dijual oleh KelompokTernakItik Putri Mandiri adalah telur konsumsi dan itik afkir. Jumlah telur yang dijual tergantung dari telur yang di-hasilkan. Pada saat produksi telur meningkat bisa dijual sekitar 500-700 butir/hari. Harga telur adalah Rp.1.250 - Rp. 1.400 per butir

Itik afkir adalah itik yang sudah tidak menghasilkan telur lagi, atau produksi telurnya telah menurun (sekitar di bawah 45\%) (Wakhid,2010). Harga jual itik afkir sekitar Rp.32.000 per ekor sampai Rp.35.000 per ekor, penjualan itik afkir ini hanya dilakukan ketika ada pengafkiran. Kegiatan penjualan telur dapat dilihat pada Gambar 6 .

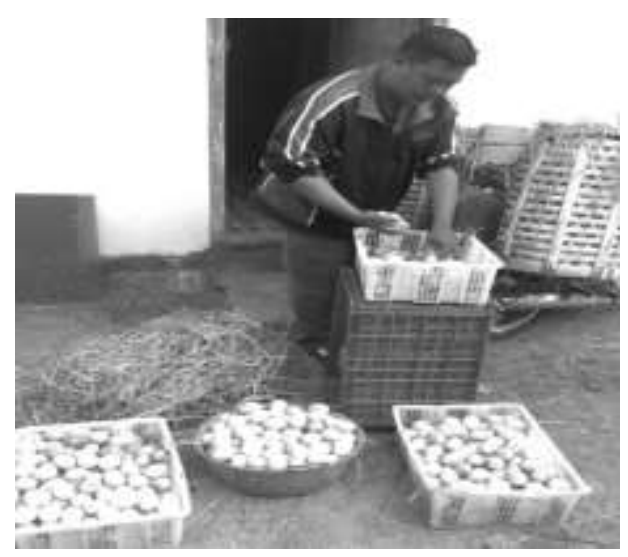

\section{Gambar 6 Kegiatan Penjualan Telur}

\section{Rantai Tataniaga}

Berbagai produk hasil budi daya itik, mulai telur (konsumsi dan tetas), DOD, hingga itik pedaging maupun itik petelur relative bisa dipasarkan dengan mudah, baik oleh peternak sendiri maupun oleh para pedagang pengumpul yang biasa datang rutin ke peternakan itik (Wakhid, 2010). Pemasaran hasil produksi dilakukan oleh ketua kelompok, penjualan telur biasanya dibawa langsung ke pasar Rengas Dengklok atau pembeli yang datang langsung 


\section{MIMBAR \\ Agribisnis \\ ISSN 2460-4321}

Volume $1 ・$ Nomor $1 ・$ Juli 2015

ke tempat.Rantai tataniaga produk dapat dilihat pada Gambar 8.

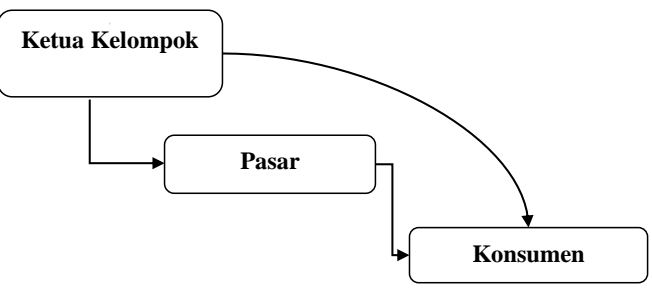

Gambar 1 Rantai Tataniaga Penjualan Produk (Konsultasi Pribadi. Kelompok Ternak Itik Putri Mandiri 2011)

\section{PENUTUP}

\section{Kesimpulan}

Berdasarkan hasil pembahasan, dapat disimpulkan bahwa:

1) Keadaan penerapan budidaya itik pada Kelompok Ternak Itik Putri Mandiri mencangkup pemberian pakan, pengambilan telur, teknik pencahayaan dan penggunaan litter, biosekuriti dan sanitasi, program pencegahan penyakit, penanganan limbah cukup baik, walaupun masih banyak yang harus diperbaiki semisal tata letak kandang dan program pemberian cahaya

2) Harga jual telur dalam pemasaran itik antara Rp. 1.200-Rp 1.400,- per telur dan harga itik afkir Rp.32.000- Rp.35.000 per ekor. Rantai. Penjualan ada yang langkung ke konsumen dan ada yang melalui pasar.

\section{Saran}

Penerapan budidaya itik pada Kelompok Ternak Itik Putri Mandiri dalam pemeliharaan sebaiknya lebih diperbaiki agar mendapatkan produksi telur meningkat, disarankan untuk dilakuakan pembuatan telur asin sebagai nilai tambah, Fungsi anggota kelompok harus ditingkatkan untuk mencapai hasil produksi yang baik.

\section{DAFTAR PUSTAKA}

Akhirany, N. 2010. Pedoman Pengawasan Biosekuriti dan Higiene terhadap Produk 2008 Unggas, http://disnaksulsel info/indeks2 php option com docman \& task dock vew\&gid $10 \&$ itemid.pdf (22 Juli 2011).
Cahyono, B. 2007. Sukses Beternak Itik Jantan Lokal Afkir Untuk Hewan Potong. Pustaka Mina. Jakarta.

Ditjen Peternakanan. 2010. Populasi Itik di Jawa Barat tahun 2005 - 2009. http://www.ditjennak.go.id/tbank2.asp?id= 4\&ket=POPULASI(11 April2011).

Hardjosworo, P, dan Rukmiasih. 2009. Permasalahan dan Pemecahan Itik. Penebar Swadaya. Jakarta.

Supriyadi. 2009. Panen Itik Pedaging dalam 6 Minggu. Penebar Swadaya. Jakarta.

Supriyadi. 2010. Panduan Lengkap Itik. Penebar Swadaya. Jakarta.

Wakhid, A. 2010. Buku Pintar Beternak Itik dan Bisnis Itik. Agro Media. Jakarta.

Windhyarti, S. 2009. Beternak Itik Tanpa Air. Penebar Swadaya. Jakarta 